\title{
Driving Force of TQM in Improving SME's Performance: The Roles of Innovation and Spiritual Capital
}

\section{Fikrotul Ulyah}

University of Jember

Fikro.fu@gmail.com

\author{
Ahmad Toha \\ University of Jember \\ toha.fisip@unej.ac.id \\ Sasongko \\ University of Jember \\ sasongko.fisip@unej.ac.id
}

\begin{abstract}
TQM concept is known as a significant driver of performance of large-scale companies. This study points out two perspectives namely direct and indirect influence associated with TQM. Specifically, it delves into the innovation and spiritual capital in improving the performance of Intako. Path analysis was carried out to shed lights on the correlation among the aforementioned aspects. There were 98 samples involved in the study. The research results confirm the influence of innovation and spiritual capital on TQM. Likewise, the same results are evident on the influence of innovation, spiritual capital, and TQM on company performance.
\end{abstract}

Keywords: Innovation, Spiritual Capital, Total Quality Management, Performance, Small-and-Medium Enterprises.

\section{INTRODUCTION}

Total Quality Management (TQM) is a quality management practice widely operationalized by large-scale companies in maintaining and optimizing customer satisfaction by implementing continuous improvements in the company's internal dynamics to produce high-quality products. TQM has been successfully applied to manufacturing companies (Chen, Lee, \& Wang, 2018; Sadikoglu \& Olcay, 2014; Valmohammadi \& Roshanzamir, 2015), service companies (Abdullahi \& Shadrack, 2018; Kiprono, 2018; Talib, Rahman, \& Qureshi, 2015, 2012), and small businesses (Imran, Abdul Hamid, \& Aziz, 2018; Kr Singh, 2011; Laxmikumari, Kumar, \& Ramana, 2014).

The implementation of TQM also has a positive impact on production costs and company revenues. TQM aims to maximize competitiveness, which is reflected on customer satisfaction, employee involvement, and continuous improvement in the quality of products, services, people, processes and the company's environment. (Prayhoego \& Devie, 2013; Olusanya \& Adegbola, 2014). Megawati, Pratiwi, \& Maruta 
(2019) and Danyen \& Callychurn (2015) emphasize 5 indicators applied in small-andmedium scale enterprise (henceforth SME) including: focus on customers, employee engagement and empowerment, management commitment, education and training, and continuous improvement.

Companies which implement TQM must find ways to best meet the needs and expectations of consumers. This creates an impetus for the company to be innovative in developing and launching products to meet the customers' needs (Setiawan \& Daromes, 2019). Innovation is specifically interpreted as an idea, practice or object considered new by an individual or other product user (Nurzamzami \& Siregar, 2016). The other previous works by Sila (2018), Kasim (2018) and Sri (2012) deal with the success of innovation in mediating the relationship between TQM and performance. The aspects of innovation which reflect openness to new things have a positive effect on TQM in improving performance.

By comparison, Masnita, Hermien \& Rasyawal (2017) reveal that innovation cannot mediate TQM on performance. In the next study, Masnita, Rahman, \& Veraldy (2019), Mahmud, Hilmi, Aspha, \& Mustapha (2019), emphasize on three types of innovations which include process, marketing and product innovation. The results show that innovation has the power to mediate TQM on SME performance. Apart from the discussion, adopting TQM requires a change in workers' attitudes which then leads to a positive goal in the business namely the achievement of profit (Shariff, Adawiyah, Saud, \& Mokhtar, 2012).

Intrinsically, TQM poses positive impact on job satisfaction, communication and perceptions in a work environment (Sani, et al., 2017). In addition, the successful implementation of TQM is strongly related to the involvement of human resources characterized by robust motivation, commitment, flexibility and fine behavior in providing service to customers (Jabeen, Shehu, \& Mamhmood, 2015). This is reflected in the values contained in spiritual capital.

Spiritual capital can encourage a competitive work environment (Heaton, et al., 2014). Spiritual performance capital has attracted attention in various fields of business. Spirituality is also considered an important foundation for achieving effective business (Lucey, 2019). Senge (in Zymonik \& Dobrowolska, 2015) highlights the importance of building learning organizations that focus on changing mentality and the need for a shared vision so that workers feel united and contribute to organizational triumph.

Spiritual capital is often associated with religion (formally), even though the two terms have different meanings. Spiritual capital is a value in business culture that emphasizes positivity. Spiritual capital focuses on interpersonal relationships, managing the mind and heart and individual behavior (Zohar \& Marshall, 2005: 97). While religion pertains to a set of rules and beliefs externally imposed (Zohar \& Marshall, 2007: 8). The concept of spiritual capital is used as a foundation for human resources in dealing with problems such as business uncertainty, dynamic environment and even planning for the future (Mir, Hassan, Egel, \& Murad, 2019). 
The results of Prakosa, Susilo, \& Aini (2018) confirm that although spiritual capital has a significant effect on performance improvement, the level of uncertainty in the answers is quite substantial. This research can account for the power of human resources beyond TQM to improve performance (Zohar \& Marshall, 2007: 53). A positive effect is also revealed in Balik, Joseph and Silaya's (2018) study. Their study delves into strong sense of purpose, trust and respect, tolerance of employee expression. The results of their analysis corroborate that spiritual capital denotes the foothold of entrepreneurs in undergoing business dynamics. In addition, the value of strength in understanding organizational goals has the potential of propelling entrepreneurs to achieve their business goals, both financially and non-financially.

Intako shopping tourism or the Bag and Suit Industry Center (Intako) Tanggulangin is one of the largest SMEs in Sidoarjo Regency engaged in leather crafts in East Java. Sidoarjo is one of the regions in East Java declared as SME city because it has a greater number of industrial centers than other cities (Soerabaia newsweek.com, 2016). Intako was founded 43 years ago and continues to survive and develop until now. Nevertheless, a disaster hit more than a quarter of craftsmen, leaving only 170 craftsmen in the company (www.m.medcom.id).

Intako's turnover before the disaster in 2005 was Rp. 16,106,117. 438. High turnover was achieved by applying aspects to TQM. Intako experienced a very significant turnover due to the disaster in 2006, which was Rp. 13,850,000 up to 2008, Rp. 9,891,000,-and began to rise in 2009 at Rp. 10,491,000. (Hurek, 2017). A number of researchers conducted studies on Intako and the suggestions for these studies were well acknowledged. However, up to now Intako's turnover has not yet demonstrated a significant increase, since it equalizes the turnover before the disaster. Spiritual capital instills the idea of mental resilience so that they can remain optimistic to survive until now. Although in some SMEs the employees always come and go, but the business owners always provide morale support to rise from adversity. Based on the description of the background, the present study is projected to analyze the following hypotheses:

Hypothesis 1: Innovation influences Total Quality Management

Hypothesis 2: Spiritual capital poses an effect on Total Quality Management

Hypothesis 3: Innovation influences the performance of Intako

Hypothesis 4: Spiritual capital influences the performance of Intako

Hypothesis 5: Total quality management affects the performance of Intako

\section{METHODOLOGY}

The present study applied quantitative approach with explanatory methods. This research was conducted at an SME known as Intako in Tanggulangin, Sidoarjo, East Java. The population involved was 170 business owners/managers of Intako with a total sample of 140 respondents who were chosen based on a set of specific criteria. Validity and reliability tests were conducted on 30 respondents outside the sample. The classic assumption tests operative in the study included normality, multicollinearity and 
heteroscedasticity. Hypothesis testing in this study was done using descriptive analysis, path analysis, $t$-test and coefficient of determination.

\section{RESULTS AND DISCUSSION}

\section{A. Result}

The research instrument test was tried out on 30 respondents outside the sample. From these test, it was found that all question items were valid and reliable. From 140 respondents, 98 questionnaires were collected and processed. In this study, 2 methods of questionnaire distribution were at play, which involved both printed and online survey. 32 respondents did not respond to the survey, and 10 others did not complete the survey. The questionnaire data were then tabulated using Microsoft Excel and then put under further analyses using SPSS 20. A classic assumption test was carried out and results indicated that the data were normally distributed as shown the data in the $\mathrm{p}-\mathrm{p}$ plot spread across the diagonal line. The analysis results demonstrated no sign of multicollinearity, which was indicated by a tolerance value of more than 0.1 and a VIF value of less than 10 . Heteroscedasticity test results also indicated that the data were spread above and below 0 . This clearly acknowledges the absence of heteroscedasticity.

Table 3.1 The Result of Regression Test

\begin{tabular}{lcccc}
\hline & $\begin{array}{c}\text { Unstandard } \\
\text { cofficients }\end{array}$ & $\begin{array}{c}\text { Standard } \\
\text { coefficient beta }\end{array}$ & Tstatistic & Sig. \\
\hline Constant & 54,542 & & 6,151 & 0,000 \\
\hline Innovation $\rightarrow$ TQM & 0,389 & 0,277 & 2,423 & 0,000 \\
$\mathrm{SC} \rightarrow \mathrm{TQM}$ & 0,396 & 0,329 & 3,508 & 0,007 \\
\hline Constant & 1,264 & & 0,419 & 0,000 \\
Innovation $\rightarrow$ performance & 0,064 & 0,110 & 2,344 & 0,000 \\
$\mathrm{SC} \rightarrow$ performance & 0,242 & 0,594 & 7,011 & 0,000 \\
TQM $\rightarrow$ performance & 0,200 & 0,059 & 1,988 & 0,001 \\
\hline
\end{tabular}

Table 3.2 Decomposition of Path Coefficient, Direct Influence, and Indirect Influence

\begin{tabular}{lcccc}
\hline & \multicolumn{2}{c}{ Causal Influence } & Total & Description \\
\hline & Direct & Indirect & & \\
\hline Innovation $\rightarrow$ TQM & 0,277 & - & 0,277 & Significant \\
$\mathrm{SC} \rightarrow \mathrm{TQM}$ & 0,329 & - & 0,329 & Significant \\
\hline Innovation $\rightarrow$ performance & 0,110 & $0,277 \times 0,059=0,0134$ & 0,1234 & Significant \\
$\mathrm{SC} \rightarrow$ Performance & 0,594 & $0,329 \times 0,059=0,0194$ & 0,688 & Significant \\
$\mathrm{TQM} \rightarrow$ Performance & 0,059 & - & 0,059 & Significant \\
\hline
\end{tabular}

Table 1 shows that Innovation has a significance of 0.001 , which is lower than $\alpha$ 0.05 . As a result, $\mathrm{Hl}$ is accepted. This indicates that innovation significantly influences TQM. The influence of Spiritual capital on TQM has a significance of $0.001<0.05$. This demonstrates that $\mathrm{H} 2$ is also accepted. These findings evince that the model has an $\mathrm{R}$ 
square of 0.274 or equivalent to $27.4 \%$. Put simply, TQM can be accounted for by spiritual capital and innovation. The equation in model 1 can be formulated as follows:

$\mathrm{TQM}=54,542+0,396$ Innovation + 0,389 spiritual capital $+\mathrm{e}$.

Table 1 also explicates that innovation has a significance of $0,000<0.05$, so $\mathrm{H} 3$ is accepted. H3 acceptance presumes that innovation poses a significant effect on performance. The same results are evident on spiritual capital, which is proven to have a significant effect on performance. That convincingly confirms $\mathrm{H} 4$, with a significance of $0.00<0.05$. Another significance of $0.001<0.05$ associated with TQM is also identified, meaning that TQM poses a significant effect on performance, which by implication approves H5. The model also clarifies that the value of $\mathrm{r}$ square $=0.568$ or $56.8 \%$. Performance is influenced by the spiritual capital, innovation and TQM. The regression equation in this model is stated as follow:

Performance $=1,264+0,242$ Innovation $+0,64$ spiritual capital+ 0,20 TQM+e.

\section{B. Discussion \\ 1. The Influence of Innovation on TQM}

The analysis shows that innovation has a significant effect on TQM. The indicators associated with innovation contribute to improving the role of TQM in SMEs. The positive linkages between innovation and TQM have been well acknowledged as demonstrated by their significance to TQM. The principle of continuous change is in line with innovations which are bound to the aim at refreshing and driving function in SMEs. Increased competitiveness in Indonesia stimulates Intako to sustain their improvements and withstand changes, despite their little values compared to competitors.

\section{The Influence of Spiritual Capital on TQM}

The regression results indicate that spiritual capital has a significant influence on TQM. This means that the principles in the spiritual capital have a role to play in enhancing TQM. In achieving continuous improvement, SMEs need human resources with satisfactory capital skills as portrayed by fine affective and cognitive aspects. Managing these aspects is important as it can create a positive work environment so that the goal of continuous change can be achieved

\section{The Influence of Innovation on SME's Performance}

Innovation has a significant effect on performance. This shows that innovation plays important roles in improving the performance of SMEs. However, this influence is not substantial. This idea, at some point, is confirmed by the fact that some respondents did not rely on innovation in improving performance. 


\section{The Influence of Spiritual Capital on SME's Performance}

The test results have revealed that spiritual capital poses an effect on SME's performance. Spiritual positively contribute to improving performance. This positive result can be indicated the number of respondents who believe that the management of soft-skill dimensions in company is deemed crucial to boost performance. The respondents also believe that being accompanied by inner peace brings about a positive spirit and mutual trust, which can eventually attract customers or provide comfort to customers. As a result, this sense of positivity can encourage the increment of business performance.

\section{The Influence of TQM on SME's Performance}

TQM, as illustrated in the previous table, is shown to make a positive contribution to improve performance. As a corollary, the role of TQM in mediating innovation and spiritual capital, which serve as the driving force to performance, has been confirmed. Nevertheless, the contribution is not significant. Substantial impact can only be actualized when TQM is implemented to achieve its utmost. In reality, the craftsmen unfortunately have never received any training on conducting TQM. TQM is only indirectly or partially put at play.

\section{CONCLUSION}

From the discussion, it is obvious that all hypotheses are confirmed. The research results have showed that innovation and spiritual capital pose a significant effect on SME's TQM although the effect may not be substantial. The results of the influence of innovation, spiritual capital and TQM have a significant relationship with the performance of SMEs. The magnitude of the influence of the second regression model is also insignificant. This shows that some other variables can also affect performance improvement.

This research suggests that the local district government can provide Innovation and TQM training with the aim to improve Intako's performance. Basically, Intako has applied the principles of TQM, but theoretically it has not been fully operationalized. This is the main reason why government intervention is highly required in providing training. In addition, training and welfare of employees need to be maintained and improved, so employees can bring up fresh ideas to improve Intako's performance.

\section{REFERENCES}

Abdullah, D.F. and Sofian, S. (2012) The Relationship between Intellectual Capital and Corporate Performance. Procedia-Social and Behavioral Sciences, 40, 537-541. http://dx.doi.org/10.1016/j.sbspro.2012.03.227

Abdullahi, A. A., \& Shadrack, B. (2018). Total quality management practices and performance of commercial banks in Kenya: Case of Kenya Commercial Bank Limited. International Academic Journal of Human Resource and BusinessAdministration, 
3(1), 190-207. https://doi.org/10.35942/ijcab.v3vivi .75

Adawiyah, W. R. (2011). The Relationship Between Soft TQM and Work Related Outcome: The Moderating Impact of Spirituality At The workplace (Universiti Utara Malaysia). electronc theses and dissertations. Paper 2569. https://doi.org/10.18297/etd/2569

Balik, D., Joseph, C. N., \& Silaya, M. (2018). Pengaruh Kecerdasan Spiritual, Kecerdasan Emosional terhadap keterampilan Manajerial dan Performance UKM ( Studi Pada Wirausaha Kristen Di Kota Ambon). Jurnal SOSO2, 6(7), 27-33. https://doi.org/http://dx.doi.org/10.30598/sosoq.v5i2.227

Barros, S., Sampaio, P., \& Saraiva, P. (2014). Quality Management Principles and Practices Impact on the Companies Performance. International Conference on Quality Engineering and Management, 237-247. Retrieved from https://core.ac.uk/download/pdf/55636464.pdf

Chen, R., Lee, Y., \& Wang, C. (2018). Total Quality Management \& Business Excellence Total quality management and sustainable competitive advantage: serial mediation of transformational leadership and executive ability. Total Quality Management, 0(0), 1-18. https://doi.org/10.1080/14783363.2018.1476132

Danyen, S., \& Callychurn, D. S. (2015). Total quality management success faktors and their relationships with performance measures in the food industry: A Mauritian case study. International Journal of Productivity and Quality Management, 16(3), 249-266. https://doi.org/10.1504/ IJPQM.2015.071520

Deepika, S., Anandakumar, D. S., \& Krishnamoorthy, D. V. (2016). Study on Faktors Influencing the TQM Practices and its Consequences. Bonfring International Journal of Industrial Engineering and Management Science, 6(2), 48-52. https://doi.org/10.9756/bijiems.7088

Hurek, lambertus. (2017). Sidoarjo menangi penghargaan pariwisata. Radar Surabaya. Retrieved from https://radarsurabaya.jawapos.com/read/2017/11/ 28/30103/sidoarjo-raih-dua-penghargaan-api-2017

Imran, M., Abdul Hamid, S. N. B., \& Aziz, A. B. (2018). The influence of TQM on export performance of SMEs: Empirical evidence from manufacturing sector in Pakistan using PLS-SEM. Management Science Letters, 8(5), 483-496. https://doi.org/10.5267/j.msl.2018.3.003

Jabeen, R., Shehu, A. M., \& Mamhmood, R. (2015). Total quality management dimensions and SME performance: a quantitative approach. International Postgraduate Business Journal, 7(1), 21-35. Retrieved from http://oyagsb.uum.edu.my/index.php/ipbj-list-of-issue

Kasim, K. (2018). Role of Internal and Eksternal Organizational Factors in TQM ImplementationL A systematic Literarure Review and Theoritical Framework. International Journal of Quality \& Reliability Management , 35(5), 1014-1033. doi:https://doi.org/10.1108/IJQRM-10-2016-0180

Kiprono, D. J. (2018). Total Quality Management Practices and Performance of Airlines in Kenya: Case of Air Kenya Express Limited. International Academic Journal of 
Human Resource and Business Administration, 3(4), 377-396. https://doi.org/10.35942/ijcab.v3iiv.44

Kr Singh, R. (2011). Analyzing the interaction of faktors for success of total quality management in SMEs. Asian Journal on Quality, 12(1), 6-19. https://doi.org/10.1108/15982681111140516

Laxmikumari, Kumar, V., \& Ramana, V. (2014). TQM : A Quality and Performance Enhancer. International Journal of Engineering and Science, 4(8), 91-94. https://doi.org/10.1080/10686967.2004.11919131

Lucey, T. A. (2019). Examining a measure of spiritual capital: Perceptions of business and education majors. Citizenship, Social and Economics Education, 18(1), 315.https://doi.org/10.1177/2047173418823543

Mahmud, N., Hilmi, M. F., Aspha, Y., \& Mustapha, A. (2019). Total Quality Management and Sme Performance: the Mediating Effect of Innovation in Malaysia. Asia Pasific MAnagement Accounting Journal, 14(1), 202-217. https://doi.org/101016/j.sbspro.2014.04.026

Masnita, Y., Rahman , A., \& Veraldy, A. (2019). Inovasi Memediasi TQM dan KIneja Perusahaan pada Sektor UKM. Jurnal Manajemen Industri dan Logistik, 03(02), 155163. doi:10.30988/jmil.v3i2.138

Mir, U. R., Hassan, S. S., Egel, E., \& Murad, H. S. (2019). An integrated framework for organizational performance enhancement through spirituality. Journal of the Research Society of Pakistan, 2(56), 233-243. https://doi.org/10.5539/ijbm.v7n5p3

Nurzamzami, A., \& Siregar, E. H. (2016). Peningkatan Daya Saing UMKM Alas Kaki di Kecamatan Ciomas, Kabupaten Bogor dan Implikasinya terhadap Strategi Pemasaran. Jurnal Manajemen Dan Organisasi, 5(1), 15-29. https://doi.org/10.29244/jmo.v5il.12127

Olusanya, S. O., \& Adegbola, E. A. (2014). Impact of Total Quality Management Practice on Small and Medium Scale Enterprises in Nigeria. (A Case Study of Small Business Owners in Lagos). IOSR Journal of Business and Management, 16(4), 3945. https://doi.org/10.9790/487x-16453945

Prayhoego, C., \& Devie. (2013). Analisa Pengaruh Total Quality Management Terhadap Keunggulan Bersaing dan Performance Perusahaan. Business Accounting Review, 1(2), 236-245. https://doi.org/10.33536/jiem.v4il.304

Pudjihastuti, S. H., \& Kurdaningsih, D. M. (2018). Peran mediasi keunggulan kompetitif pada faktor determinan Performance bisnis UKM di sentra tenun batik di Jawa Tengah Pendahuluan. Jurnal Siasat Bisnis, 22(2), 111-131. https://doi.org/10.20885/jsb.vol22.iss2.artl

Rofiaty. (2012). Inovasi dan Performance: Knowladge Sharing Behaviour pada UKM. Malang: Universitas Brawijaya Press.

Sadikoglu, E., \& Olcay, H. (2014). The Effects of Total Quality Management Practices on Performance. Laboratory Management Information Systems: Current Requirements and Future Perspectives, 1(17), 996-1027. https://doi.org/10.1155/2014/537605 
Sadikoglu, E., \& Zehir, C. (2010). Investigating the effects of innovation and employee performance on the relationship between total quality management practices and firm performance: An empirical study of Turkish firms. International Journal of Production Economics, 127(1), 13-26. https://doi.org/10.1016/j.ijpe.2010.02.013

Setiawan, A. A., \& Daromes, F. (2019). Total Quality Management as a Driving Mechanism for Profit and Innovation to Company Performance: Empirical Study of Small Medium Enterprise's. Business and Economic Journal, 26(01), 70-81. Retrivied from https://www.unisbank.ac.id/ojs/index.php /fe3/article/download/7498/2648/

SIla, I. (2018). Country and Sector effect on the relationship among TQM practice and key performance measures. Internationa Journal of Productivity and Performance Management, 67(8), 1371-1393. doi:https://doi.org/10.1108/ IJPPM-11-2017-0297

Sil, M., Kassiavera, S., \& Belly, N. M. (2018). Analisis Total Quality Management terhadap Performance Manajerial pada Usaha Mikro, Kecil dan Menengah dalam Era Globalisasi. The National Conferences Management and Business (NCMAB) 2018 "Pemberdayaan Dan Penguatan Daya Saing Bisnis Dalam Era Digital," 208-220. https://doi.org/10.35448/jte.v12i2.4460

Soerabia newsweek.com. (2016, Oktober ). Sidaoarjo Layak Menjadi Kota UKM Indonesia. Retrieved from http://www.surabayanewsweek.com/2016/10/ sidoarjo-layak-menjadi-kota-ukm.html

Sri, H. (2012). Peran Inovasi: Pengembangan Kualitas produk dan Performance Bisnis . Jurnal Manajemen dan Kewirausahaan, 82-88.

Sweis, R. J., Elhawa, N. A., \& Sweis, N. J. (2019). Total quality management practices and their impact on performance: Case study of Royal Jordanian Airlines. International Journal of Business Excellence, 17(2), 245-263. https://doi.org/10.1504/IJBEX.2019.097546

Talib, F., Rahman, Z., \& Qureshi, M. N. (2012). Total quality management in service sector: A literature review. International Journal of Business Innovation and Research, 6(3), 259-301. https://doi.org/10.1504/IJBIR.2012 .046628

Tjiptono , F., \& Diana , A. (2003). Total Quality Management. Yogyakarta : Andi Offset .

Turan, H. (2015). Taylor's "Scientific Management Principles": Contemporary Issues in Personnel Selection Period. Journal of Economics, Business and Management, 3(11). https://doi.org/10.7763/joebm.2015.v3.342

Valmohammadi, C., \& Roshanzamir, S. (2015). The guidelines of improvement: Relations among organizational culture, TQM and performance. International Journal of Production Economics, 164, 167-178. https://doi.org/10.1016/j.ijpe.2014.12.028

Walker, E., \& Brown , A. (2004). What Success Faktors Are important to Small Business Owners. International Small Business Journal, 37(6), 407-429.

Web Resmi Bank Indonesia. www.bi.go.id

Zohar, Danah, \& Marshall, I. (2007). SQ: Kecerdasan Spiritual. Bandung: PT Mizan Pustaka. 
Zohar, Danah, \& Marshall, I. N. (2004). Spiritual capital : wealth we can live by. 1st ed. Danah Zohar, Ian Marshall. Retrieved from http://ezproxy.library. tamu.edu/login?url=http://search.ebscohost.com/login.aspx?direct=true\& \&db=cat03 318a\&AN=tamug. $2261423 \&$ site=eds-live

Zymonik, Z., \& Dobrowolska, A. (2015). Spiritual capital as the fourth capital in a TQM organization. Zarzadzanie i Finanse Journal of Management and Finance, 13(2), 147155. Retrieved from http://cejsh.icm.edu.pl/cejsh/ element/bwmetal.element.desklight-9bf2e582-cdc3-4d45-9960-2712dbecac8 